\title{
QUALITY CHARACTERISTICS AND SHELF LIFE OF PEPPER FRUITS AS INFLUENCED BY STORAGE CONDITIONS AND PEPPER VARIETIES
}

\section{El-Sayed G. Khater ${ }^{1 *}$, Mohamed T. Afify ${ }^{2}$}

${ }^{1}$ Assoc. Prof. of Ag. Eng., Fac. of Ag., Benha U., Egypt.

${ }^{2}$ Assist. Prof. of Ag. Eng., Fac. of Ag., Benha U., Egypt.

*E-mail: alsayed.khater@fagr.bu.edu.eg

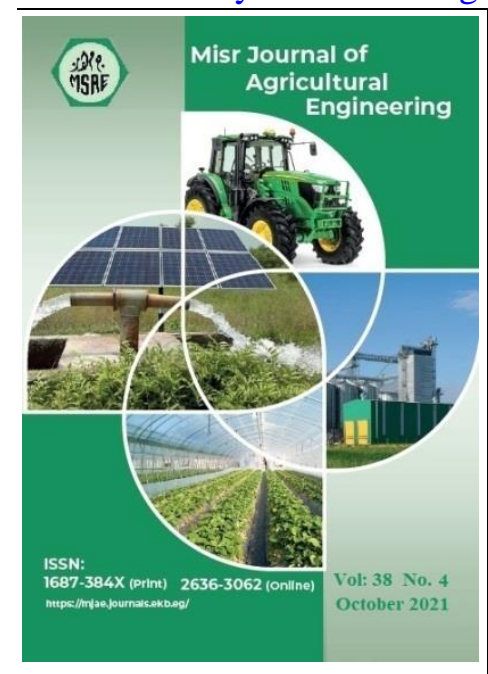

○ Misr J. Ag. Eng. (MJAE)

\section{Keywords:}

Pepper; Physical properties;

Mechanical properties;

Storage temperature; Weight loss; Shelf life, TSS

\section{ABSTRACT}

The main aim of this research was to study the effect of storage conditions (room temperature and refrigeration temperature) on the quality (weight loss and chemical composition change on pepper fruits) and shelf life of different varieties of pepper (Alonso Red, Lumos Yellow, Relampago Red, Dicaprio Yellow, Dicaprio Green, Relampago Orange, Conical Century White, Rush Red and Rush Green). The results indicated that, the accumulated weight loss of pepper fruits increases with increasing storage period. The highest value of the accumulated weight loss of pepper fruits (43.22\%) was found for green Rush variety at room temperature $\left(25^{\circ} \mathrm{C}\right)$ after 20 days storage, while, the lowest value of the accumulated weight loss (25.44\%) was found for yellow Lumos variety at cold storage $\left(10^{\circ} \mathrm{C}\right)$ after 46 days storage. The shelf- life of pepper fruits increased from 20 to 46 days for all varieties under study, when the storage temperatures decreased from 25 to $10^{\circ} \mathrm{C}$. Average total soluble solids (TSS) increased from 3.50 to $5.63 \%$ when the storage temperature changed from 10 to $25^{\circ} \mathrm{C}$ for all varieties used in this experiment.

\section{INTRODUCTION}

$\mathrm{P}$ epper (Capsicum annuum L.) is one of the most important among vegetable crops throughout the world. Pepper fruits have a wide variety of shapes, sizes, colors, and include many different varieties of hot and sweet peppers. Peppers are generally considered as a balanced source of most of essential nutrients, high content of vitamins, important antioxidants, rich in flavonoids and phytochemicals (Costa et al., 2009 and Maria et al., 2010). Dimensions, geometric mean diameter, mass, surface area, volume, apparent volumetric, real volumetric, packaging coefficient, porosity, sphericity and static friction angle were measured through experiment. These properties determine the quality and identification of correlation among these properties makes quality control easier (Jannatizadeh, 2008). The design of processing machines, storage structures and environmental parameter controls depend on the properties of bio-materials. These properties are useful in the analysis and determination of the efficiency of a machine or an operation, 
development of new products and new equipment and final quality of new products (Mohsenin, 1986 and Khater and Bahnasawy, 2016).

Watada et al. (1996) and Roura et al. (2000) reported that storage temperature is an essential parameter in maintaining quality and shelf life of fresh produce. Low temperature prolongs storage life by reducing respiration rate and senescence, as well as reducing growth of spoilage microorganisms. Optimum storage temperatures vary among commodity types. For fruits and vegetables susceptible to chilling injury, excessively low temperature can also cause chilling injury and resulted in loss of quality and shelf-life. Improper storage temperatures may adversely affect quality factors such as appearance, flavor, and color. In addition, product deterioration may proceed rapidly. Therefore, it is important to select the optimum storage temperature to maintain quality and extend storage-life of fresh fruits and vegetables (Kim et al., 2004 and Khater and Bhnasawy, 2016).

The most effective method of maintaining quality and controlling decay of peppers is by a rapid cooling after harvest followed by storage at low temperature with a high relative humidity. However, peppers are very sensitive to chilling injury which limits storage temperature to above $10^{\circ} \mathrm{C}$. On the other hand, without refrigeration, peppers turn color and deteriorate in a few days as a result of rapid aging and parasitic infections (Hardenburg et al., 1986). Proper storage temperature selection is the most important parameter for storage of chilies and peppers. Optimum storage temperature range for chilies is reported between 7 to $13{ }^{\circ} \mathrm{C}$ for 2 - 3 weeks (Rico et al., 2002).

Temperature of $10^{\circ} \mathrm{C}$ and $90-95 \%$ relative humidity maintain sweet pepper quality satisfactorily for a period of up to 12 - 18 days (Sealand, 1991). Low temperature storage remains the most effective tool for maintaining quality and extending shelf life, but it results in chilling injury. However, seal packaging ameliorates chilling injury in many fresh products by prevention of water loss (Ben-Yoshua, 1987).

Proper storage system reduces wastes, adds value and makes the product qualitatively and quantitatively acceptable. Respiration rate and gas exchange through the package material are the processes involved in creating a modified atmosphere inside a package that will extend shelf life of fresh bell peppers (Susana et al., 2002). Bell peppers are not suitable for long term cold storage; the recommended range of storage temperatures for bell peppers is from 7 to $13{ }^{\circ} \mathrm{C}$, depending on the variety and the maturity stage (Paull, 1995).

Postharvest losses of fresh horticultural crops ranged from 5 to $25 \%$ in developed countries and of 20 to $50 \%$ in developing countries (Kader, 2007). Optimum storage conditions are required to reduce these losses. Storage temperature is considered as main factors affecting the quality during storage. Also, one of the export problems is the lack of characteristics of fruits pepper which affect the value of pepper prices and their quality during storage. Therefore, the main aim of this work is to study the properties of different varieties of pepper fruits and investigate the quality and shelf-life of the fruit under different storage conditions.

\section{MATERIALS AND METHODS}

The experiment was carried out at Agricultural and Bio-Systems Engineering Department, Faculty of Agriculture, Moshtohor, Benha University, Qaluiobia Governorate, Egypt, during the period of March to May, 2020. 


\subsection{Materials}

Pepper (Capsicum annuum L.) was brought from the Experimental Research Station at the Faculty of Agriculture, Moshtohor, Benha University after harvesting at the same maturity stage. Nine pepper varieties namely, Alonso Red, Lumos Yellow, Relampago Red, Dicaprio Yellow, Dicaprio Green, Relampago Orange, Conical Century White, Rush Red and Rush Green Peppers were used in this study to measure and determine the physical and mechanical properties, also to study the effect of storage temperature on the quality and shelf life of pepper varieties.

\subsection{Methods}

\subsubsection{Physical and mechanical properties}

\subsubsection{Physical properties}

For each pepper fruit, three linear dimensions were measured by using a digital vernier caliper (Model TESA 1p65- Range $0-150 \mathrm{~mm} \pm 0.01 \mathrm{~mm}$, Swiss) with an accuracy of $\pm 0.01 \mathrm{~mm}$, including length (L), width (W) and thickness (T) as shown in fig. 1. The rind thickness of pepper fruit rind was also measured by digital vernier caliper. The mass of fruit pepper was measured by electric digital balance (Model Vibra - Range 0-12000 g $\pm 0.01 \mathrm{~g}$, Japan). Fruits geometric mean diameter $\left(\mathrm{D}_{\mathrm{g}}\right)$ and surface are $(\mathrm{S})$ were calculated as suggested by Mohsenin (1986):

$$
\begin{gathered}
\mathrm{D}_{\mathrm{g}}=\sqrt[3]{\mathrm{LWT}} \\
\mathrm{S}=\pi\left(\mathrm{D}_{\mathrm{g}}\right)^{2}
\end{gathered}
$$

Where:-

$\mathrm{D}_{\mathrm{g}}$ is the geometric mean diameter, $\mathrm{mm}$

$\mathrm{L}$ is the length of pepper fruits, $\mathrm{mm}$

$\mathrm{W}$ is the width of pepper fruits, $\mathrm{mm}$

$\mathrm{T}$ is the thickness of pepper fruits, $\mathrm{mm}$

$\mathrm{S}$ is the fruit surface area, $\mathrm{mm}^{2}$

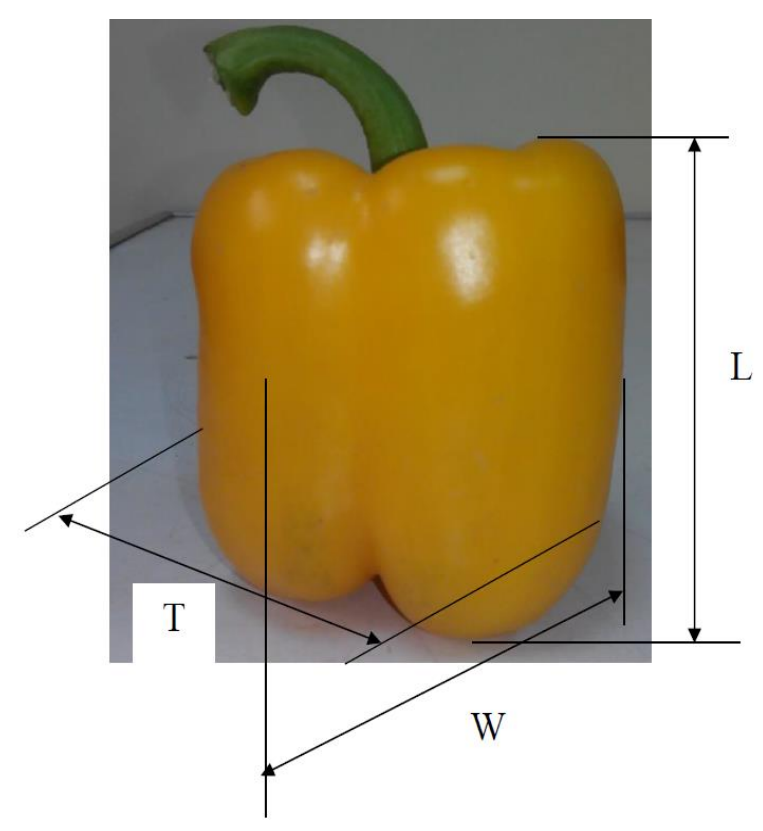

Fig. 1. Dimensions of pepper fruit: length (L), width (W) and thickness (T) 
Water displacement method was used for determining the fruits measured volume $\left(\mathrm{V}_{\mathrm{m}}\right)$. The criteria projected area (CPA) was calculated as suggested by Mohsenin (1986):

$$
\mathrm{CPA}=\frac{A P_{1}+A P_{2}+A P_{3}}{3}
$$

Where:

$\mathrm{PA}_{1}$ is the projected area perpendicular to $\mathrm{L}$ direction of fruit, $\mathrm{mm}^{2}$

$\mathrm{PA}_{2}$ is the projected area perpendicular to $\mathrm{T}$ direction of fruit, $\mathrm{mm}^{2}$

$\mathrm{PA}_{3}$ is the projected area perpendicular to $\mathrm{W}$ direction of fruit, $\mathrm{mm}^{2}$

Oblate spheroid $\left(\mathrm{V}_{\mathrm{osp}}\right)$ and ellipsoid $\left(\mathrm{V}_{\text {ellip }}\right)$ shapes were calculated as:

$$
\begin{array}{r}
\mathrm{V}_{\text {osp }}=\frac{4 \pi}{3}\left(\frac{\mathrm{L}}{2}\right)\left(\frac{\mathrm{W}}{2}\right)^{2} \\
\mathrm{~V}_{\text {ellip }}=\frac{4 \pi}{3}\left(\frac{\mathrm{L}}{2}\right)\left(\frac{\mathrm{W}}{2}\right)\left(\frac{\mathrm{T}}{2}\right)
\end{array}
$$

Where:

$$
\begin{aligned}
& V_{\text {osp }} \text { is the oblate spheroid volume, } \mathrm{mm}^{3} \\
& V_{\text {ellip }} \text { is the ellipsoid shape volume, } \mathrm{mm}^{3}
\end{aligned}
$$

The moisture content of randomly selected pepper fruits of each variety was determined according to ASAE Standard (1984). Three samples of each pepper fruits were randomly selected and weighed on an electrical digital balance. Drying oven (Model 655F Cat. No. 13245-655, range 50 to $300{ }^{\circ} \mathrm{C}$, Canada) at $105^{\circ} \mathrm{C}$ until a constant weight was reached. The true density was calculated for pepper fruits mass per unit volume. For each case, the determination was replicated three times and the mean was considered.

\subsubsection{Mechanical properties}

The hardness was measured by Hardness meter (Model GY-1-Range $20-150 \mathrm{~N} \mathrm{~cm}^{-2} \pm 1 \mathrm{~N}$ $\mathrm{cm}^{-2}$, China). Crushing load implies the partial or complete destruction of pepper fruits. Crushing load was measured by compressive and tensile device loads ((Model MP2E- Range $0-2000 \mathrm{kN} \pm 0.1 \mathrm{kN}$, Italy).

Crushing load implies the partial or complete destruction of pepper fruits, pepper fruit was sat upon a flat plate until the cross-head of a handmade apparatus was brought in contact with the fruit and compression force was applied by adding weights or loads until permanent (destruction) was caused and then the loads were recorded (Khater et al., 2014).

\subsubsection{Storage conditions:}

The pepper fruits were stored at cold storage of $10^{\circ} \mathrm{C}(85 \pm 5 \%$ relative humidity $)$ and room temperature of $25 \pm 3^{\circ} \mathrm{C}$ ( $60 \pm 5 \%$ relative humidity). The weight loss was measured every two days. The TSS was measured at the start and end of the experiment by Refractometer (Model HR-010-Range 0- 10\% Brix $\pm 0.1 \%$ Brix, Japan).

\section{RESULTS AND DISCUSSIONS}

\subsection{Physical properties}

Table 1 shows the dimensions (length, width and thickness), rind thickness of pepper fruit, geometric mean diameter, mass, moisture content and density of the pepper fruits for different varieties (Alonso Red, Lumos Yellow, Relampago Red, Dicaprio Yellow, Dicaprio Green, 
Relampago Orange, Conical Century White, Rush Red and Rush Green). It could be seen that the length, width and thickness of pepper fruit value ranged from 71.858 to $200.246,29.038$ to 89.692 and 21.964 to $82.974 \mathrm{~mm}$, respectively, for different varieties of pepper fruits. The lowest value of length, width and thickness of pepper fruits were 71.858, 29.038 and 21.964 $\mathrm{mm}$ were found for orange (Relampago), red (Rush) and red (Rush), respectively. While, the highest value of length, width and thickness of pepper fruits were 200.246, 89.692 and 82.974 $\mathrm{mm}$ were found for red (Rush), yellow (Dicaprio) and green (Dicaprio), respectively. These dimensions data are very important in handling, packing and storage capacity determination. These results agreed with those obtained by Shahbazi and Rahmati (2015) whose found that the length, width and thickness of pepper fruit were 84.254, 84.415 and $74.071 \mathrm{~mm}$, respectively.

Table 1: The dimensions, rind thickness of pepper fruit, geometric mean diameter, mass, moisture content and density for different varieties of pepper fruits.

\begin{tabular}{|c|c|c|c|c|c|c|c|c|c|}
\hline \multicolumn{2}{|c|}{ Pepper Variety } & \multicolumn{3}{|c|}{ Dimensions, mm } & \multirow{2}{*}{$\begin{array}{c}\text { Rind } \\
\text { thickness of } \\
\text { fruit, } \mathrm{mm}\end{array}$} & \multirow{2}{*}{$\begin{array}{c}\text { Geometric } \\
\text { mean } \\
\text { diameter, } \\
\mathrm{mm}\end{array}$} & \multirow{2}{*}{ Mass, g } & \multirow{2}{*}{$\begin{array}{c}\text { Moisture } \\
\text { Content, } \\
\% \text { w.b }\end{array}$} & \multirow{2}{*}{$\begin{array}{c}\text { True } \\
\text { Density, } \\
\mathrm{kg} \mathrm{m}^{-3}\end{array}$} \\
\hline & & Length & Width & Thickness & & & & & \\
\hline \multirow{7}{*}{ Sweet } & Red (Alonso) & 84.277 & 77.24 & 73.54 & 6.572 & 78.202 & 201.364 & 89.567 & 774.832 \\
\hline & Yellow (Lumos) & 91.518 & 79.431 & 76.506 & 6.369 & 82.183 & 226.029 & 90.687 & 759.537 \\
\hline & $\begin{array}{c}\text { Red } \\
\text { (Relampago) }\end{array}$ & 78.232 & 84.952 & 81.55 & 6.119 & 81.509 & 210.036 & 93.019 & 712.478 \\
\hline & $\begin{array}{l}\text { Yellow } \\
\text { (Dicaprio) }\end{array}$ & 79.942 & 89.692 & 82.054 & 5.810 & 83.689 & 232.692 & 90.046 & 693.294 \\
\hline & $\begin{array}{c}\text { Green } \\
\text { (Dicaprio) }\end{array}$ & 78.39 & 87.356 & 82.974 & 5.606 & 82.801 & 200.846 & 89.785 & 651.327 \\
\hline & $\begin{array}{c}\text { Orang } \\
\text { (Relampago) }\end{array}$ & 71.858 & 86.79 & 79.524 & 5.896 & 79.103 & 190.734 & 90.345 & 699.781 \\
\hline & $\begin{array}{l}\text { White (Conical } \\
\text { century) }\end{array}$ & 130.538 & 48.034 & 43.092 & 3.465 & 64.567 & 90.588 & 92.712 & 607.710 \\
\hline \multirow{2}{*}{ Hot } & Red (Rush) & 200.246 & 29.038 & 21.964 & 2.837 & 50.185 & 52.135 & 92.305 & 652.383 \\
\hline & Green (Rush) & 194.036 & 31.708 & 26.598 & 3.144 & 54.623 & 65.989 & 88.790 & 690.487 \\
\hline
\end{tabular}

The results indicated that the rind thickness of pepper fruit ranged from 2.837 to $6.572 \mathrm{~mm}$. The lowest value of rind thickness of pepper fruits $(2.837 \mathrm{~mm})$ was found for red (Rush), on the other hand, the highest value of rind thickness of pepper fruits $(6.572 \mathrm{~mm})$ was found for red (Alonso).

The results also indicated that the geometric mean diameters of the pepper fruits were 78.202, 82.183, 83.679, 82.801, 79.103, 64.571, 50.185 and 54.623 mm for Alonso Red, Lumos Yellow, Relampago Red, Dicaprio Yellow, Dicaprio Green, Relampago Orange, Conical century White, Rush Red and Rush Green varieties of pepper fruits, respectively.

Regarding the mass of pepper fruit value ranged from 52.135 to $232.692 \mathrm{~g}$ for different varieties of pepper fruits. The highest value of the mass of pepper fruit was $232.692 \mathrm{~g}$ was found for yellow (Dicaprio) variety, while, the lowest value of the mass of pepper fruit was $52.135 \mathrm{~g}$ was obtained for red (Rush) variety. 
The results revealed that the moisture content of fruit were 89.567, 90.687, 93.019, 90.046, 89.785, 90.345, 92.305 and 88.790 \% w.b, for Alonso Red, Lumos Yellow, Relampago Red, Dicaprio Yellow, Dicaprio Green, Relampago Orange, Conical century White, Rush Red and Rush Green varieties of pepper fruits, respectively. The highest value of moisture content of pepper fruit (93.019\% w.b) was found for red (Relampago) variety, while, the lowest value of moisture content of pepper fruit $(88.790 \%$ w.b) was obtained for green (Rush) variety.

The true density of fruit were 774.832, 759.537, 712.478, 693.294, 651.327, 699.781, 607.710, 652.383 and $690.487 \mathrm{~kg} \mathrm{~m}^{-3}$, for Alonso Red, Lumos Yellow, Relampago Red, Dicaprio Yellow, Dicaprio Green, Relampago Orange, Conical Century White, Rush Red and Rush Green varieties of pepper fruits, respectively The highest value of true density of pepper fruit $\left(774.832 \mathrm{~kg} \mathrm{~m}^{-3}\right.$ ) was found for red (Alonso) variety, while, the lowest value of true density of pepper fruit $\left(607.710 \mathrm{~kg} \mathrm{~m}^{-3}\right)$ was obtained for white (Conical Century) variety. The trend of the results agreed with those obtained by Ilori et al., (2010).

Table 2 shows the surface area, projected area, criteria projected area, measured volume, oblate spheroid volume and ellipsoid shape volume for different varieties of the pepper fruits. It could be seen that the surface area of the pepper fruits were 192.293, 212.536, 208.672, 220.530, 215.542, 197.038, 131.024, 79.147 and $93.878 \mathrm{~cm}^{2}$ for Alonso Red, Lumos Yellow, Relampago Red, Dicaprio Yellow, Dicaprio Green, Relampago Orange, Conical Century White, Rush Red and Rush Green varieties of pepper fruits, respectively. These results agreed with those obtained by Ikrang and Okoko (2014) whose found that the surface area of pepper fruit was $83.67 \mathrm{~cm}^{2}$. Additionally, the highest value of surface area of pepper fruit $(220.530$ $\mathrm{cm}^{2}$ ) was found for yellow (Dicaprio) variety, on the other hand, the lowest value of surface area of pepper fruit $\left(79.147 \mathrm{~cm}^{2}\right)$ was obtained for red (Rush) variety.

Table 2: Surface area, projected area (AP), criteria projected area (CPA), measured volume, oblate spheroid volume $\left(\mathrm{V}_{\text {osp }}\right)$ and ellipsoid shape volume $\left(\mathrm{V}_{\text {ellip }}\right)$ for different varieties of pepper fruits.

\begin{tabular}{|c|c|c|c|c|c|c|c|c|c|}
\hline \multicolumn{2}{|c|}{ Pepper variety } & $\begin{array}{c}\text { Surface } \\
\text { Area, } \mathrm{cm}^{2}\end{array}$ & $\begin{array}{l}\mathrm{AP} 1, \\
\mathrm{~cm}^{2}\end{array}$ & $\begin{array}{l}\mathrm{AP} 2, \\
\mathrm{~cm}^{2}\end{array}$ & $\begin{array}{l}\mathrm{AP} 3 \\
\mathrm{~cm}^{2}\end{array}$ & $\begin{array}{l}\mathrm{CPA}, \\
\mathrm{cm}^{2}\end{array}$ & $\begin{array}{l}\text { Volume } \\
, \mathrm{cm}^{3}\end{array}$ & $\begin{array}{l}\mathrm{V}_{\text {osp }}, \\
\mathrm{cm}^{3}\end{array}$ & $\begin{array}{l}\mathrm{V}_{\text {ellip }} \\
\mathrm{cm}^{3}\end{array}$ \\
\hline \multirow{7}{*}{ Sweet } & Red (Alonso) & 192.293 & 65.187 & 62.043 & 56.842 & 257.381 & 264.098 & 251.308 & 61.357 \\
\hline & $\begin{array}{l}\text { Yellow } \\
\text { (Lumos) }\end{array}$ & 212.536 & 72.717 & 70.130 & 60.926 & 293.053 & 303.187 & 292.377 & 67.925 \\
\hline & $\begin{array}{c}\text { Red } \\
\text { (Relampago) }\end{array}$ & 208.672 & 66.470 & 63.786 & 69.281 & 291.610 & 295.641 & 283.637 & 66.512 \\
\hline & $\begin{array}{l}\text { Yellow } \\
\text { (Dicaprio) }\end{array}$ & 220.530 & 71.701 & 65.660 & 73.884 & 319.899 & 337.273 & 309.410 & 70.415 \\
\hline & $\begin{array}{c}\text { Green } \\
\text { (Dicaprio) }\end{array}$ & 215.542 & 68.614 & 65.054 & 72.528 & 304.443 & 314.874 & 298.172 & 68.732 \\
\hline & $\begin{array}{c}\text { Orang } \\
\text { (Relampago) }\end{array}$ & 197.038 & 62.537 & 57.319 & 69.070 & 267.061 & 285.992 & 261.297 & 62.975 \\
\hline & $\begin{array}{l}\text { White (Conical } \\
\text { century) }\end{array}$ & 131.024 & 62.700 & 56.266 & 20.668 & 143.863 & 157.688 & 141.229 & 46.545 \\
\hline \multirow{2}{*}{ Hot } & Red (Rush) & 79.147 & 58.258 & 43.645 & 6.362 & 72.006 & 88.934 & 66.308 & 36.089 \\
\hline & Green (Rush) & 93.878 & 61.419 & 51.573 & 8.471 & 90.694 & 102.610 & 85.805 & 40.487 \\
\hline
\end{tabular}

The projected area perpendicular to $\mathrm{L}, \mathrm{T}$ and $\mathrm{W}$ directions of fruit were 58.130 to 72.717 , 43.645 to 70.130 and 6.362 to $72.528 \mathrm{~cm}^{2}$, respectively, for different varieties of pepper fruits. The criteria projected area of the pepper fruits were 61.357, 67.925, 66.512, 70.415, 
68.732, 62.975, 46.545, 36.089 and $40.487 \mathrm{~cm}^{2}$ for Alonso Red, Lumos Yellow, Relampago Red, Dicaprio Yellow, Dicaprio Green, Relampago Orange, Conical century White, Rush Red and Rush Green varieties of pepper fruits, respectively. The highest value of criteria projected area of pepper fruit $\left(70.415 \mathrm{~cm}^{2}\right)$ was found for yellow (Dicaprio) variety, while, the lowest value of criteria projected area of pepper fruit $\left(36.089 \mathrm{~cm}^{2}\right)$ was obtained for red (Rush) variety.

The measured, oblate spheroid and ellipsoid shape volume of pepper fruit values ranged from 72.006 to $319.899,88.934$ to 337.273 and 66.308 to $309.410 \mathrm{~cm}^{3}$ for different pepper varieties, respectively. The highest value of measured, oblate spheroid and ellipsoid shape volume of pepper fruit $\left(319.899,337.273\right.$ and $\left.309.410 \mathrm{~cm}^{3}\right)$ were found for yellow (Dicaprio) variety, while, the lowest value of measured, oblate spheroid and ellipsoid shape volume of pepper fruit $\left(72.006,88.934\right.$ and $66.308 \mathrm{~cm}^{3}$ ) were obtained for red (Rush) variety. The measured, oblate spheroid and ellipsoid shape volume of pepper fruit are important in handling and processing operations.

\subsection{Mechanical properties}

Table 3 shows the hardness and crushing load of the pepper fruits. The results indicated that the hardness of the pepper fruits ranged from 14.18 to $18.213 \mathrm{~N} \mathrm{~cm}^{-2}$. The highest value of hardness of pepper fruit $\left(18.213 \mathrm{~N} \mathrm{~cm}^{-2}\right)$ was found for red (Alonso) variety, while, the lowest value of hardness of pepper fruit $\left(14.18 \mathrm{~N} \mathrm{~cm}^{-2}\right)$ was obtained for red (Rush) variety.

The crushing load of the pepper fruits ranged from 43.687 to 203.348 and 25.742 to 163.262 $\mathrm{N}$ for vertical and horizontal positions, respectively. The highest value of crushing load of pepper fruit (203.348 and 163.262 N) were found for red (Alonso) and red (Relampago) varieties, respectively. While, the lowest value of crushing load of pepper fruit (43.687 and $25.742 \mathrm{~N}$ ) were found for green (Rush) and red (Rush) varieties, respectively.

Table 3: Some of the mechanical properties for different varieties of pepper fruits.

\begin{tabular}{lcccc}
\hline & & \multirow{2}{*}{ Hepper variety } & \multicolumn{2}{c}{ Crushing Load, N } \\
\cline { 3 - 4 } & Red (Alonso) & 18.213 & 203.348 & 161.415 \\
& Yellow (Lumos) & 17.038 & 183.883 & 149.927 \\
& Red (Relampago) & 16.954 & 198.611 & 163.262 \\
\multirow{3}{*}{ Sweet } & Yellow (Dicaprio) & 16.503 & 182.714 & 150.708 \\
& Green (Dicaprio) & 15.991 & 172.669 & 149.940 \\
& Orang (Relampago) & 16.663 & 178.971 & 150.727 \\
& White (Conical & 15.8 & 93.265 & 46.936 \\
& century) & & & \\
\multirow{3}{*}{ Hot } & Red (Rush) & 14.18 & 43.780 & 25.742 \\
& Green (Rush) & 14.4 & 43.687 & 29.013 \\
\hline
\end{tabular}

\subsection{Effect of storage conditions on weight loss of different varieties pepper fruits}

Fig. 2 shows the accumulated weight loss of pepper fruits that stored under different storage conditions. The results indicate that the accumulated weight loss of pepper fruits increases with increasing storage period. It could be seen that the accumulated weight loss of pepper fruits increased from 2.92 to $32.93,2.64$ to $27.97,1.83$ to $33.05,1.59$ to $29.50,2.93$ to 30.87 
and 2.14 to $28.35 \%$, when the storage period proceeds from 2 to 26 days at room temperature of $25 \pm 3{ }^{\circ} \mathrm{C}$ and relative humidity of $60 \pm 5 \%$ (room temperature) for Alonso Red, Lumos Yellow, Relampago Red, Dicaprio Yellow, Dicaprio Green and Relampago Orange, respectively.
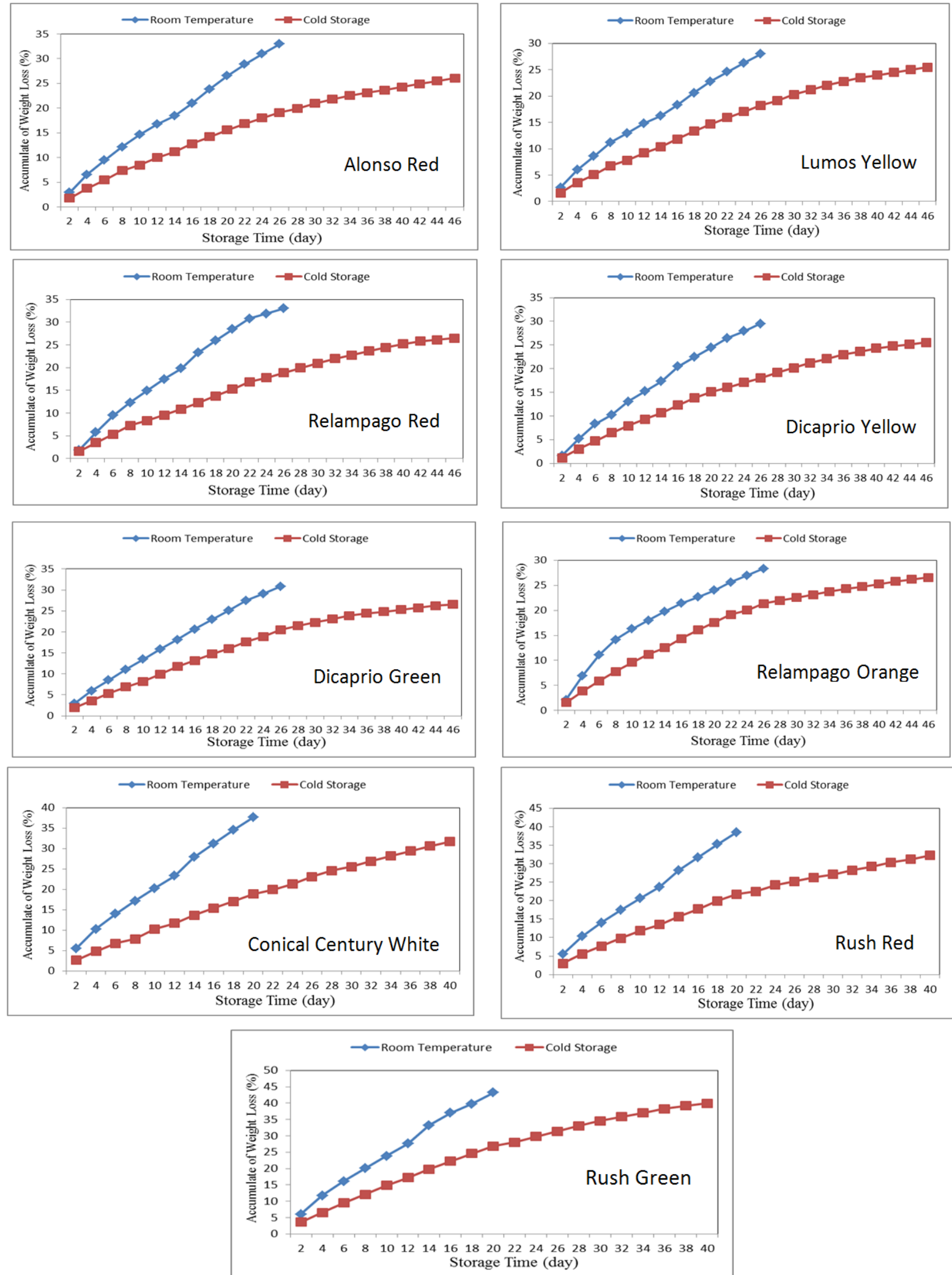

Fig. 2. The accumulated weight loss of different varieties pepper fruits at different storage conditions. 
While, the accumulated weight loss of pepper fruits increased from 1.75 to $26.05,1.62$ to $25.44,1.59$ to $26.49,1.13$ to $25.51,1.89$ to 26.59 and 1.54 to $26.56 \%$, when the storage period increased from 2 to 46 days at cold storage of $10^{\circ} \mathrm{C}$ and relative humidity of $85 \pm 5 \%$ for the same previous mentioned species. Also, the accumulated weight loss of pepper fruits increased from 5.43 to $37.63,5.48$ to 38.54 and 6.07 to $43.22 \%$, when the storage period increased from 2 to 20 days at room temperature of $25 \pm 3^{\circ} \mathrm{C}$ and relative humidity of $60 \pm 5$ $\%$ for Conical Century White, Rush Red and Rush Green, respectively. While, the accumulated weight loss of pepper fruits increased from 2.59 to $31.68,3.03$ to 32.23 and 3.63 to $39.91 \%$, when the storage period increased from 2 to 40 days at cold storage of $10^{\circ} \mathrm{C}$ and relative humidity of $85 \pm 5 \%$ for Conical Century White, Rush Red and Rush Green, respectively.

The results show the accumulated weight loss of pepper fruits stored at room temperature (25 $\left.\pm 3^{\circ} \mathrm{C}\right)$ higher than of the fruits stored at cold storage $\left(10^{\circ} \mathrm{C}\right)$. Storing the pepper under room temperature $\left(25 \pm 3^{\circ} \mathrm{C}\right.$ and $60 \pm 5 \%$ relative humidity) lost $33.56 \pm 3.99 \%$ of its weight during the storage period (20 to 26 days). Meanwhile, it lost $28.94 \pm 3.65 \%$ of its weight when it was stored at cold storage $\left(20^{\circ} \mathrm{C}\right.$ and $85 \pm 5 \%$ relative humidity) for all varieties under study. Generally, the higher storage temperature, the higher vapor pressure deficit, the higher weight losses of fruits. These results were in agreement with those obtained by Khater and Bahnasawy (2016). The highest value of accumulated weight loss of pepper fruits was $43.22 \%$ was found for green Rush variety at room temperature of $25^{\circ} \mathrm{C}$ after 20 days storage, while, the lowest value of accumulated weight loss of pepper fruits was $25.44 \%$ was found for yellow Lumos variety at cold storage of $10^{\circ} \mathrm{C}$ after 46 days storage.

Regression analysis was carried out to find a relation between the accumulated weight loss of pepper fruits and storage times for different storage conditions and varieties. Equation 6 shows the most appropriate form for the relationship between the fruit accumulated weight loss and storage times for different storage condition and varieties. The constants of these equations and coefficient of determination are listed in Table 4.

$$
\mathrm{WL}=\mathrm{at} \mathrm{t}^{2}+\mathrm{bt}+\mathrm{c}
$$

Where:-

WL is the accumulated weight loss of pepper fruits (\%)

$\mathrm{t}$ is the storage time (day)

\subsection{Effect of storage conditions on the shelf life of different varieties pepper fruits}

Table 5 shows the effect of storage conditions on the shelf life of pepper fruits for different varieties. The results indicated that the shelf life of pepper fruits increases with decreasing storage temperature, where, it increased from 26 to 46 days for Alonso Red, Lumos Yellow, Relampago Red, Dicaprio Yellow, Dicaprio Green and Relampago Orange varieties under the storage temperatures decreased from 25 to $10^{\circ} \mathrm{C}$. While, it increased from 20 to 40 days for Conical Century White, Rush Red and Rush Green varieties with the storage temperatures decreased from 25 to $10^{\circ} \mathrm{C}$. Cold storage gave the fruit a long shelf life as twice as the room temperature gave, which may be due to that the cold storage decrease the respiration and transpiration rate which in turn the affects the shelf life of the fruits. 
Table 4: The constants a, b, c and coefficient of determination for accumulated weight loss of pepper fruits at the storage times for different storage conditions and pepper varieties.

\begin{tabular}{ccccccccc}
\hline \multirow{2}{*}{ Pepper Variety } & \multicolumn{6}{c}{ Constants and coefficient of determination } \\
\cline { 2 - 9 } & \multicolumn{7}{c}{ Room Temperature } & \multicolumn{5}{c}{ Cold Storage } \\
\cline { 2 - 9 } & $\mathrm{a}$ & $\mathrm{B}$ & $\mathrm{c}$ & $\mathrm{R}^{2}$ & $\mathrm{~A}$ & $\mathrm{~b}$ & $\mathrm{c}$ & $\mathrm{R}^{2}$ \\
\hline Red (Alonso) & -0.024 & 2.785 & 0.858 & 0.998 & -0.033 & 1.881 & 0.004 & 0.999 \\
Yellow (Lumos) & -0.034 & 2.519 & 0.905 & 0.997 & 0.028 & 1.768 & -0.154 & 0.999 \\
Red (Relampago) & -0.079 & 3.737 & -1.571 & 0.998 & -0.029 & 1.831 & -0.113 & 0.999 \\
Yellow & -0.058 & 3.123 & -1.118 & 0.999 & -0.031 & 1.861 & -0.628 & 0.999 \\
(Dicaprio) & & & & & & & & \\
Green (Dicaprio) & -0.037 & 2.856 & 0.213 & 0.999 & -0.039 & 2.112 & -0.278 & 0.998 \\
Orang & -0.126 & 3.744 & -0.039 & 0.989 & -0.049 & 2.279 & 0.574 & 0.999 \\
(Relampago) & & & & & & & & \\
White (Conical & 0.025 & 3.798 & 2.243 & 0.998 & -0.024 & 2.027 & 0.613 & 0.999 \\
century) & & & & & & & & \\
Red (Rush) & -0.017 & 3.801 & 2.289 & 0.998 & -0.048 & 2.526 & 0.563 & 0.999 \\
Green (Rush) & -0.076 & 4.945 & 1.568 & 0.998 & -0.061 & 3.196 & 0.417 & 0.999 \\
\hline
\end{tabular}

Table 5: The effect of storage conditions on the self life of different varieties pepper fruits.

\begin{tabular}{cccc}
\hline \multirow{2}{*}{ Pepper Variety } & \multicolumn{2}{c}{ Self Life of pepper fruits, day } \\
\cline { 3 - 4 } & Room Temperature & Cold Storage \\
\hline \multirow{4}{*}{ Sweet (Alonso) } & 26 & 46 \\
& Yellow (Lumos) & 26 & 46 \\
& Red (Relampago) & 26 & 46 \\
& Yellow (Dicaprio) & 26 & 46 \\
& Green (Dicaprio) & 26 & 46 \\
& Orang (Relampago) & 26 & 46 \\
\multirow{4}{*}{ Hot } & White (Conical century) & 20 & 40 \\
& Red (Rush) & 20 & 40 \\
& Green (Rush) & 20 & 40 \\
\hline
\end{tabular}

\subsection{Effect of storage conditions on TSS}

Table 6 shows the effect of storage conditions on the TSS change in pepper fruits for different varieties. The results indicated that the TSS in pepper fruits increases with increasing storage temperature. It could be seen that the TSS increased from 6.624 to $9.817 \%(32.53 \%)$ and 6.624 to $11.362 \%(41.70 \%)$ with the storage temperatures increased from 10 to $25^{\circ} \mathrm{C}$, respectively, for Alonso Red variety. It increased from 6.072 to $9.093 \%$ (33.22\%) and 6.072 to $11.117 \%$ (45.38\%), 5.116 to $8.055 \%$ (36.49\%) and 5.116 to $10.568 \%$ (51.59\%), 4.738 to $8.016 \%(40.89 \%)$ and 4.738 to $10.109 \%(53.13 \%), 3.165$ to $7.264 \%(56.43 \%)$ and 3.165 to $9.891 \%(68.00 \%), 3.949$ to $7.880 \%(49.89 \%)$ and 3.949 to $10.194 \%(61.26 \%), 4.001$ to $7.875 \%(49.19 \%)$ and 4.001 to $10.194 \%(60.75 \%), 6.716$ to $9.912 \%(32.24 \%)$ and 6.716 to $11.580 \%(42.00 \%)$ and 3.534 to $7.473 \%(52.71 \%)$ and 3.534 to $9.726 \%(63.66 \%)$ for Lumos 
Yellow, Relampago Red, Dicaprio Yellow, Dicaprio Green, Relampago Orange, Conical Century White, Rush Red and Rush Green, respectively, with the storage temperatures increased from 10 to $25^{\circ} \mathrm{C}$. These results were in agreement with those obtained by Yonemoto et al. (2002) and Bahnasawy and Khater (2014).

Additionally, the highest value of TSS change in pepper fruits was $68.00 \%$ was found for Dicaprio Green variety at storage temperature $25^{\circ} \mathrm{C}$, while, the lowest value of TSS change in pepper fruits was $32.24 \%$ was found for Rush Red variety at storage temperature $10{ }^{\circ} \mathrm{C}$.

Table 6: The effect of storage conditions on TSS change in pepper fruits.

\begin{tabular}{lccccc}
\hline \multirow{2}{*}{\multicolumn{1}{c}{ Pepper Variety }} & \multicolumn{4}{c}{ Total Soluble Solids, \% } \\
\cline { 3 - 6 } & \multicolumn{2}{c}{ Room Temperature } & \multicolumn{2}{c}{ Cold Storage } \\
\cline { 2 - 5 } & Refore & After & Before & After \\
\hline \multirow{6}{*}{ Sweet (Alonso) } & 6.624 & 11.362 & 6.624 & 9.817 \\
& Yellow (Lumos) & 6.072 & 11.117 & 6.072 & 9.093 \\
& Red (Relampago) & 5.116 & 10.568 & 5.116 & 8.055 \\
& Yellow (Dicaprio) & 4.738 & 10.109 & 4.738 & 8.016 \\
& Green (Dicaprio) & 3.168 & 9.891 & 3.168 & 7.264 \\
& Orang (Relampago) & 3.949 & 10.005 & 3.949 & 7.880 \\
& White (Conical century) & 4.001 & 10.194 & 4.001 & 7.875 \\
& Rot (Rush) & 6.716 & 11.580 & 6.716 & 9.912 \\
& Red & 3.534 & 9.726 & 3.534 & 7.473 \\
\hline
\end{tabular}

\section{CONCLUSIONS}

The experiment was carried out successively to determine some physical and mechnical properties of some varieties of pepper (Alonso Red, Lumos Yellow, Relampago Red, Dicaprio Yellow, Dicaprio Green, Relampago Orange, Conical Century White, Rush Red and Rush Green) and study the effect of storage conditions on pepper fruits quality for different varieties. The obtained results can be summarized as follows:

- The length, width and thickness of pepper fruit value ranged from 71.858 to 200.246, 29.038 to 89.692 and 21.964 to $82.974 \mathrm{~mm}$, respectively. The thickness of pepper fruit and the geometric mean diameter of the pepper fruits ranged from 2.837 to 6.572 and 50.185 to $83.679 \mathrm{~mm}$, respectively.

- The surface area of pepper fruit values ranged from 79.147 to $220.530 \mathrm{~cm}^{2}$. The moisture content of the pepper fruits ranged from 88.790 to $93.019 \%$. The density of the pepper fruits ranged from 607.710 to $774.832 \mathrm{~kg} \mathrm{~m}^{-3}$.

- The mass of pepper fruit value ranged from 52.135 to $232.692 \mathrm{~g}$. The measured, oblate spheroid and ellipsoid shape volume of pepper fruit values ranged from 72.006 to $319.899,88.934$ to 337.273 and 66.308 to $309.410 \mathrm{~cm}^{3}$ for different pepper varieties, respectively.

- The hardness of the pepper fruits ranged from 14.18 to $18.213 \mathrm{~N} \mathrm{~cm}^{-2}$. The crushing load (vertical and horizontal) of the pepper fruits ranged from 43.687 to 203.348 and 25.742 to $163.262 \mathrm{~N}$ for vertical and horizontal, respectively. 
- The highest value of the accumulated weight loss of pepper fruits (43.22\%) was found for green Rush variety at room temperature of $25^{\circ} \mathrm{C}$ after 20 days storage, while, the lowest value of the accumulated weight loss of pepper fruits $(25.44 \%)$ was found for yellow Lumos variety at cold storage of $10{ }^{\circ} \mathrm{C}$ after 46 days storage.

- The shelf life of pepper fruits increased from 20 to 46 days for all varieties under study, when the storage temperatures decreased from 25 to $10^{\circ} \mathrm{C}$.

- Average total soluble solids (TSS) increased from 3.50 to $5.63 \%$ when the storage temperature changed from 10 to $25^{\circ} \mathrm{C}$ for all varieties.

\section{REFERENCES}

ASAE Standard, 1984. ASAE 5352.1. moisture measurement. American Society of Agric. Eng. 2950 Niles Road, St. Joseph, MI 49085-9659.

Bahnasawy, A.H., Khater, E.G., 2014. Effect of wax coating on the quality of cucumber fruits during storage. J. Food Process. Technol. 5 (6): 339. doi:10.4172/21577110.1000339

Ben-Yoshua, S. (1987). Transpiration, Water Stress and Gas exchange. In: J. Weichmann, (ed.), Postharvest Physiology of vegetables, Marsel Dekkar, New York.

Costa, L.V., Lopes R., Lopes M.T.G., De Figueiredo A.F., Barros W.S. and Alves S.R.M., 2009. Cross compatibility of domesticated hot pepper and cultivated sweet pepper. Crop Breeding and Applied Biotechnology 9:37-44.

Hardenburg, R.E., Watada A.E. and Wang C.Y., 1986. The commercial storage of fruits, vegetables, and florist and nursery stocks. pp. 23-25, U.S. Dept. Agric. Handbook No. 66, Washington, DC.

Ikrang, E.G. and Okoko J.U., 2014. Physical properties of some tropical fruits necessary for handling. Food Science and Quality Management, 23: 39- 45.

Ilori, T.A., Raji.A.O and Kilanko O.O., 2010. Some physical properties of selected vegetable. Journal of Agricultural and Veterinary Sciences, 2: $101-109$.

Jannatizadeh, M.H., 2008. A study on some chemical and physico-mechanical properties of three sweet cherry varieties (prunus avium L.) in Turkey. Journal of Food Engineering, 74: $568-575$.

Kader, A.A., 2007. Biología y tecnología poscosecha: Un panorama. In Tecnología Poscosecha de Productos Hortofrutícolas. $3^{\text {a }}$ edición. Kader, A. (Ed.). University of California, Division of Agriculture and Natural Resources, Oakland, California, USA, pp. 43-54.

Khater, E.G. and Bahnasawy A.H., 2016. Watermelon fruits properties as affected by storage conditions. Misr J. Agri. Eng., 33 (1): 101 - 122.

Khater, E.G., Bahnasawy A.H. and Ali S.A., 2014. Physical and Mechanical Properties of Fish Feed Pellets. J. Food Process. Technol. 5 (10): 378. doi: 10.4172/21577110.1000378 
Kim, J.G., Luo Y., and Gross K.C., 2004. Quality and shelf-life of salad savoy under different storage temperatures. J. Kor. Soc. Hort. Sci., 45(6):307-311.

Maria, S., Zapata P., Castillo S., Guillen F. and Martinez-Romero D., 2010. Antioxidant and nutritive constituents during sweet pepper development and ripening are enhanced by nitrophenolate treatments. J. Food Chem., 118:497 - 503.

Mohsenin, N.N., 1986. Physical properties of plant and animal materials second revised. Gordon and Breach Sci. Publ., New York

Paull, R. E., 1995. Chilling injury of crops of tropical and subtropical origin. In C. Y. Wang (Ed.), Chilling injury of horticultural crops, 17-36.

Rico, D., Martin-Diana A.B., Barat J.M. and Barry-R Y.C., 2002. Extubating and measuring the quality of fresh cut fruits and vegetables: A review. Trends in Food Sci. Technol., 18: 373 - 386.

Roura, S.I., Davidovich L.A. and Valle C.E. 2000. Quality loss in minimally processed Swiss chard related to amount of damaged area. Lebensmittel Wissenschaft Technol., 33:53-59.

Sealand (1991). Shipping guide to perishables. Sea land service Inc., PO Box 800, Iselim, New Jersey 08830, USA.

Shahbazi1, F. and Rahmati1 S., 2015. Mass modeling of green bell pepper fruit with some physical characteristics. http://confnews.um.ac.ir/images/41/conferences/iecfp2013/151_1.pdf.

Susana, C. F., Oliveira F.A.R. and Brecht J. K., 2002. Modelling respiration rate of fresh bell peppers and vegetables for modified atmosphere packages: a review. Journal of Food Engineering, 52: 99-119.

Watada, A.E., Ko N.P. and Minott D.A., 1996. Factors affecting quality of fresh-cut horticultural products. Postharvest Biol. Technol. 9:115-125.

Yonemoto, Y., Higuchi, H. and Kitano, Y., 2002. Effect of storage temperature and wax coating on ethylene production, respiration and shelf-life in cherimoya fruit. J. Japan. Soc. Hort. Sci., 71 (5): 643 - 640. 
خواص الجودة والعمر التخزينى لثمار اصناف مختلفة من القلقل نتيجة ظروف التخزين

السيد جمعه خاطر' و محمد تهامى عفيفى

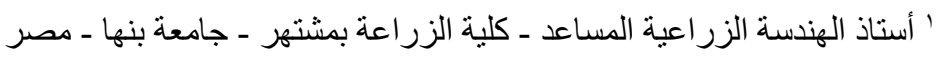

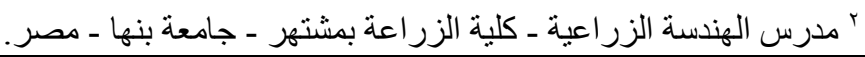

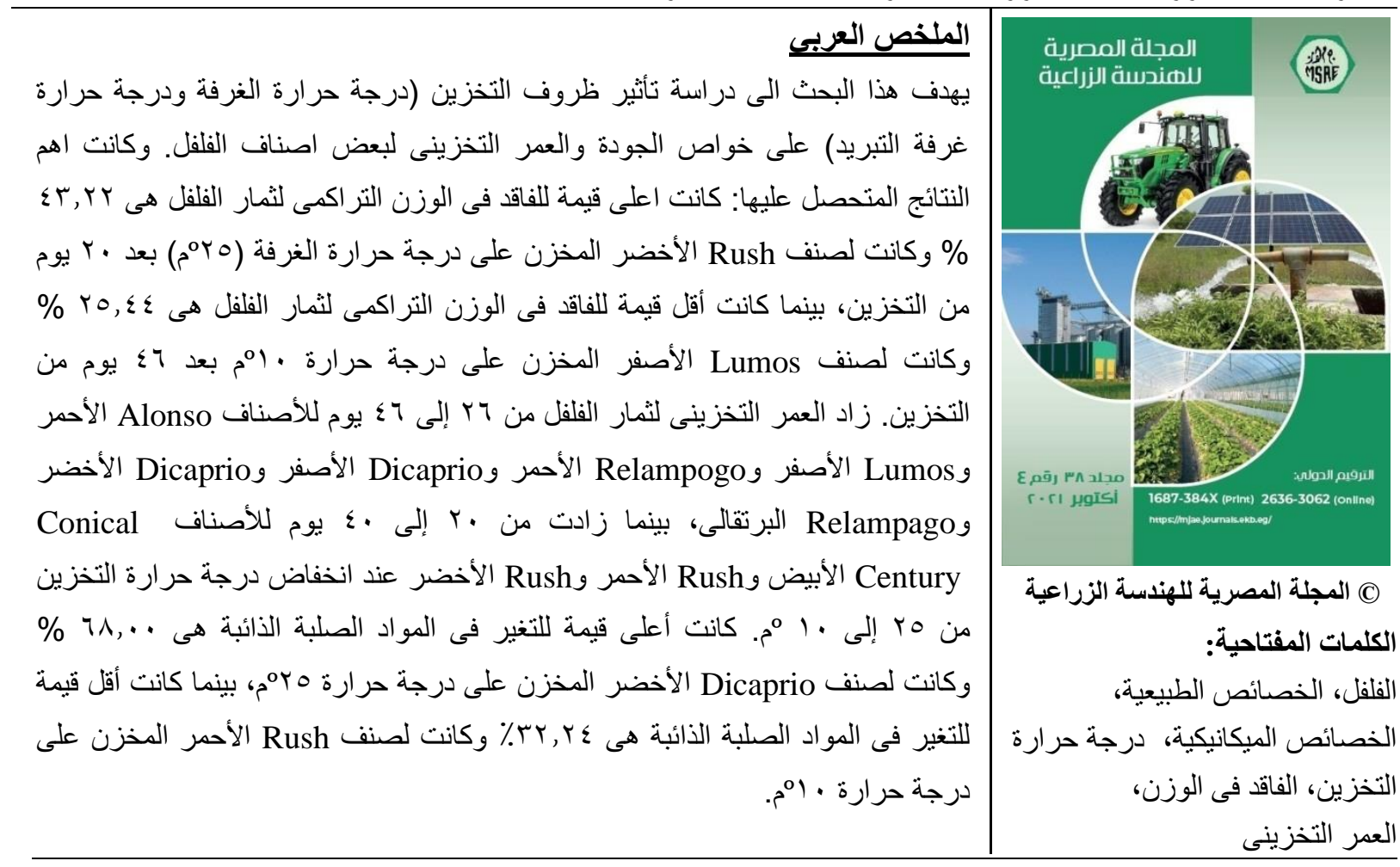

